\title{
Some economic and engineering aspects of the construction of new railway lines in Northern Canada, with particular reference to the Great Slave Lake railway
}

by

\author{
A. V. Johnston, B.Sc., M.E.I.C.
}

Mr A. H. Cantrell (Chief Civil Engineer, British Railways, Southern Region, Waterloo) said that he had had the pleasure of meeting $\mathrm{Mr}$ Johnston nearly five years before when he went over to Canada and the United States. At that time one of the things the visitors were anxious to see was how the Canadians carried out their track maintenance, but the visit was early in March and no maintenance was done because the ballast and formation were frozen. As Mr Johnston had explained, great difficulty was experienced in maintaining the track in such conditions, and various measures had to be taken.

40. Mr Cantrell had been under the impression, from pictures he had seen and articles he had read, that Canadian trains were extremely long and had to climb very steep gradients. So far Mr Johnston had not referred to length and weight of trains, but as the gradient on the Great Slave Lake line was limited to 1 in 166, perhaps it was not one of their steepest and therefore traction would not be any great difficulty.

41. The C.N.R. were to be congratulated on the speed at which this work was done. In planning a line like this clearly the first thing was to earn revenue as early as possible. Were there any other considerations besides ore traffic which had caused this particular route to be chosen? It was not through inhabited areas, and was mainly agricultural.

42. He had noticed that an extensive soils examination had been carried out. It would be interesting to know whether this determined the route or whether the carrying of agricultural products and lumber would fix the exact alignment.

43. The problem of the clay areas had obviously been a very difficult one and he had every sympathy with the Author in this respect. In Great Britain great difficulty was experienced in maintaining tracks that went through clay areas.

44. Being ignorant of Canada Mr Cantrell had been puzzled by the mention of the large volume of traffic down the Mackenzie river to the Arctic Ocean. He could not imagine what the object was of taking anything into the Arctic Ocean, which surely led to nowhere except the North Pole.

45. With regard to aerial survey, obviously it was the modern trend of carrying out a survey for a line like this. In Great Britain aerial survey was being used to quite a considerable extent but chiefly for bringing maps up to date. On the Southern Region some aerial surveys were done a few years ago to get full details of a slip which had occurred at Folkestone Warren, and from this he had realized how accurately the contours for an area could be determined. But in the case of the Great Slave Lake Railway it appeared from the Paper that the area was covered to a large extent by forest and he could not understand how an aerial survey could be accurate. Perhaps the Author would say something about this.

46. The Author had mentioned muskeg, and Mr Cantrell imagined this would

* Proc. Instn civ. Engrs, vol. 29, November 1964, pp. 571-588. 
cause great difficulty. Apparently such areas were avoided by choosing a slightly different route.

47. The permafrost areas were, he understood, those areas in which the subsoil was permanently frozen, and it would seem that whatever was put there would have to be able to withstand the frost. He noticed that the ballast laid appeared to be soft and not resistant to frost. It would be useful to have some comments about this.

48. He noticed from the Paper that the formation was $20 \mathrm{ft}$ wide, but as the track was normal gauge he wondered why this was. So it appeared that the track passed on one side of the formation, and he assumed the rest of the formation was used for approach for maintenance purposes.

Professor D. C. Robertson (Civil Engineering Department, University of Cape Town) said that the Author had mentioned the annual tonnage to be moved but nowhere had he indicated train loads. Assuming a 2000-ton freight train (which was high) and a pay load of 1300 tons, approximately 500 trains per year would be needed to shift loads in one direction. This meant that two up- and two down-trains per day would be needed, assuming unidirectional traffic at the outset. This meant 100000 train miles per year or at the transportation cost of $\$ 2300000, \$ 23$ per trainmile, which was high by most standards.

50. The maintenance charge of $\$ 2000$ per mile was low, assuming one track labourer per two miles plus platelayers' wages. This did not leave much for other maintenance--repairs after washaways, painting steelwork, making good eroded embankments, etc.

51. Referring to $\S 15$, Professor Robertson said it seemed to repeat if not contradict the previous one.

52. He referred to Col. Sir Ralf Emerson's paper in the Proceedings of March $1959^{1}$ which gave a very concise account of how photogrammetry was applied for surveys for new railways.

53. What appeared to be the staking-out process and the preparation of the longitudinal section was described in $\$ 15$. Given the grade line intersections, vertical curve data, formation widths and side slopes, a computer would print out earthworks quantities. It was not clear at this stage why new quantities should be calculated after the new set of aerial photographs had been taken.

54. Professor Robertson said that scant attention had been paid to drainage in $\$ 33$. This aspect required a good deal of care especially as earthworks concentrate ran off. A certain amount of well-reasoned investigation into catchment areas, percentage run-offs and rainfall characteristics usually paid handsome dividends. To this might be added the observation of flood levels.

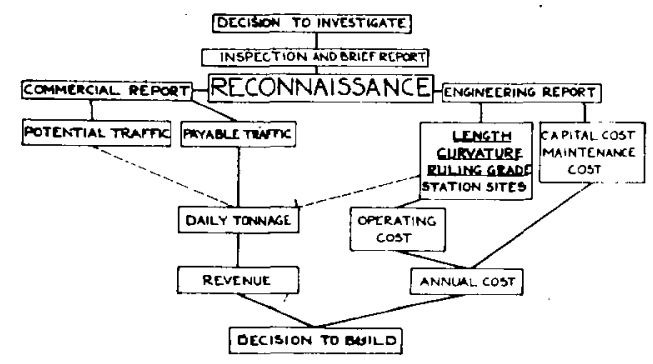

FIG. 9: INVESTIGATION FOR A RAILWAY 
55. Referring to Fig. 9, Professor Robertson said that once a decision to investigate a new railway project had been made, an inspection followed by a brief report in general terms was made.

56. The reconnaissance which followed was a very important part of the project. It was carried out in two parallel yet quite clearly connected investigations. On one side was the commercial report and on the other the engineering report. No matter how the latter was carried out, whether by examining 1:50 000 maps made by aerial survey or by traversing the ground by jeep or on foot, the object was to fix distance, curvature, ruling grade, other details such as station sites, and finally the capital cost. The linkage between these factors and the subsequent operation of the line was vital. The significance of length was self-evident. It fixed capital costs and running times. It also governed operating costs as when locomotive sections were affected. Curvature affected maintenance costs. A. M. Wellington's book, ${ }^{2}$ published 80 years ago, was still valid in this connexion.

57. Ruling grade could be a matter of choice. It affected length slightly but its main lasting effect was on train loads and hence the number of trains per day and hence operating costs. In this respect the weight of rail (which determined tractive effort) must be linked with the train loads.

58. Finally, station sites were most important. The length of station site was governed by the tare load of an empty train and the number of station sites determined by the number of trains per day, assuming a single line. Hence the close interaction between daily tonnage, ruling grade, locomotive characteristics, and weight of track were indicated.

59. There were further refinements. If the load was unidirectional, the ruling grade could be made steeper in the direction of the empty traffic. This point, however, required careful consideration in a developing country. During development heavy capital goods travelled in one direction, but after a period of years, when the country was producing, the bulk of the tonnage might be reversed. Not many engineers thought as far ahead as this because ruling grade was so often dictated by the natural characteristics of the country traversed.

60. Finally, the decision to build or not should be influenced by non-existent but potential traffic. 'Supply creates demand' was a very old economic law which still held good. It was wise to err a little on the optimistic side when estimating revenue partly because of concealed inflation of currency and partly because of external economics. Experience in a developing country had proved this.

Mr A. N. Butland (Chief Civil Engineer, British Railways Board) said that he was interested in the similarity of analysis of traffic that was made in Canada with that in Great Britain. It was interesting to note that in the industrialized and semiindustrialized belt, extending perhaps 250 miles north of the U.S. border, the Canadians too were closing unremunerative lines and seeking to concentrate their traffic on those lines where the big bulk flows such as grain and ore and minerals generally could be expected to survive. In the short-term economical judgment of such lines, where the question of a line's existence was at stake, or the potential traffic was thought to be short term, it would be interesting to know whether the C.N.R. used what was now being found a very helpful economic device in Britain-making an assessment of discounted cash flows.

62. A good deal of the erection of steel bridge work and nearly all the track laying was done, he noticed, by railway personnel. This kind of work not only lent interest to the railway engineering life but ensured that engineers were produced who had had considerable experience of direct labour working, and so were not only competent to go on doing such work but competent to handle fairly the contractors who inevitably would do the major portion of such work for them.

63. He wondered whether the resident engineer (known in Canada as the construction engineer) used, in relation to the daily mass of detail and necessary 
co-ordination, the critical path method, and actually drew out his networks and kept them up to date. He would have thought that to do that efficiently and honestly under those conditions must be the final proof of the value of such a method.

64. Mr Butland said it would have been interesting to hear a little more detail of the train speeds likely to be encountered on this line and the axle weights, and to know whether an $85 \mathrm{lb}$ relay rail was an $85 \mathrm{lb}$ new rail or one that in a previous life had been worn down to $85 \mathrm{lb}$. It would be interesting also to know whether, in the soil surveys carried out so systematically and tabulated for the use of the site staff, any particular standard series of tests was adopted, and whether such a series was relied upon more than any other for any particular reason.

65. It would have been useful to have a little more information of time scale. The construction time had been extraordinarily good, with the work started in 1961 and finished already. Perhaps the Author would say-knowing that the general possibilities of this area had been under discussion probably since the minerals were staked out in the 1890's - at what time the aerial surveys and active reconnaissance was started, so that one could know how long it took in Canada to plan such a line. In order to obtain all the land needed for the purpose had parliamentary powers been required, as would be the case in Britain, or was the land obtained simply by local negotiation?

Mr M. G. R. Smith (Consultant, Messrs G. Maunsell and Partners), referring to the question of road versus rail, said that it seemed that the conditions in Canada must at times be very bad indeed for road services; the weather itself must play havoc with the road, and the traffic. Road transport seemed to be expensive, and he wondered whether, as was the case in certain countries, the Government might give preference to rail construction as opposed to road construction as a more economical method of transport. He wondered whether road surfaces were in fact very severely damaged by the weather alone and whether road traffic created even worse damage.

67. The railways, apart from snow ploughs and snow fences, had to keep switches clear during very cold weather. What was the normal practice for keeping the switches clear of snow and ice, both out in isolated areas and in heavily used yards?

68. He understood that only about $12-18$ in. of the surface of the permafrost areas actually thawed and that some material had to be substituted. He would have thought that this material would be subject to frost heave. He believed that severe

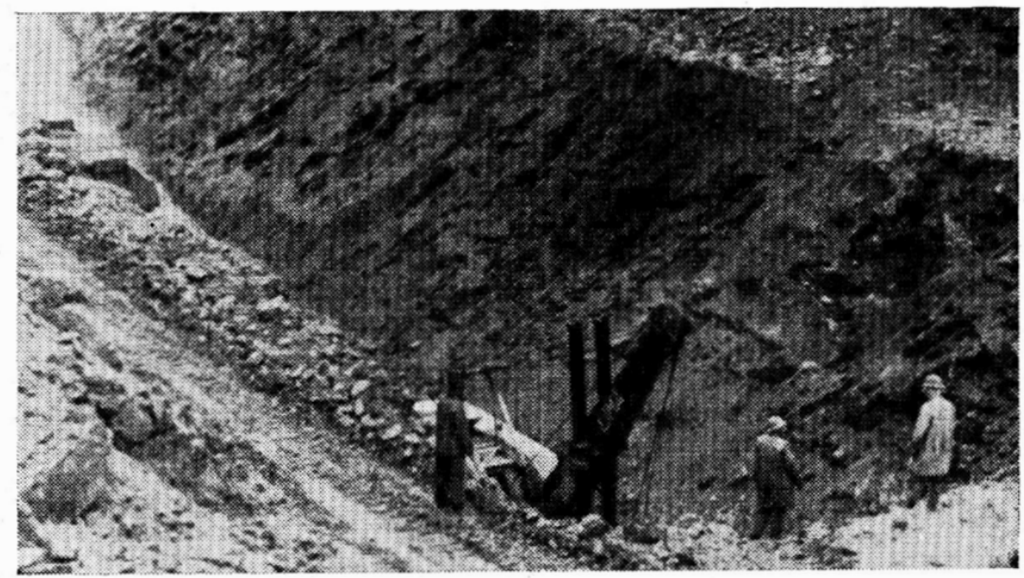

Fig. 10: Railway construction in Western Australia 


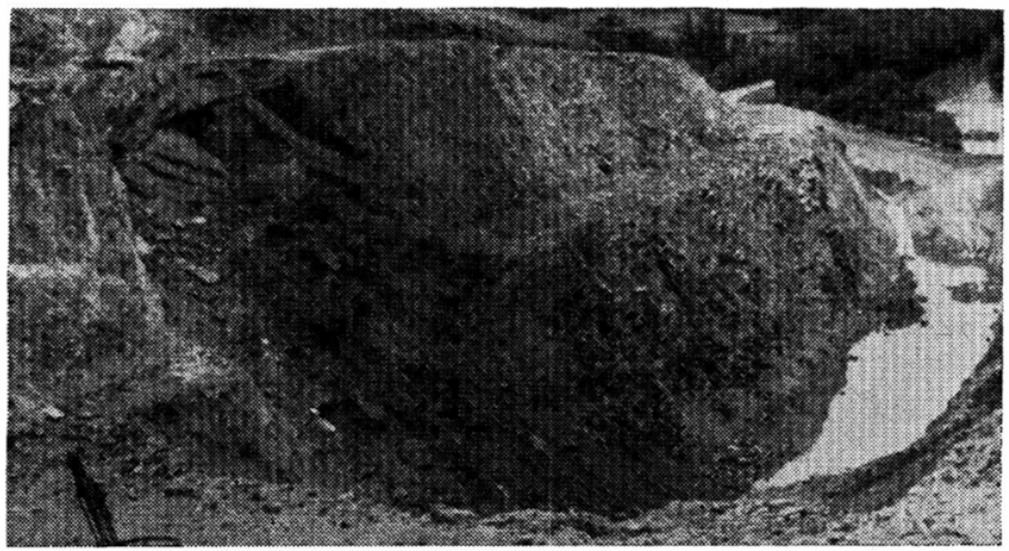

Fig. 11: DEEP ROCK CUTTING

speed restrictions had to be imposed during the period of frost heave, and that it was even necessary to insert wedges under the track to bring it up to a reasonable level for trains to run on. Did this problem still exist, and was it particularly severe in the permafrost areas or in other areas, such as the boundaries between the permafrost and the ordinary area?

69. With regard to the track construction, some of which had been done by railway employees' direct labour and some by contractors, had any figures been prepared showing the comparative costs of the two methods?

70. He understood that the fastenings would be dog spikes with base plates on timber sleepers, and that rail anchors were also used, but he wondered whether any other type of fastenings were tried and whether any decision had been reached as to the relative merits of different types.

71. Was continuous-welded rail, as used in the United States, considered at all? Perhaps the rail temperature range was such that this was quite out of the question. In Great Britain the range was about $120^{\circ} \mathrm{F}$, and it would be useful to know whether it was very much more in Canada.

72. Some mention had been made of the use of gravel ballast which was apparently sand or stone dust. Were these materials used because of the necessity of using nearby supplies, and was there a preference for crushed stone if possible, or were these the materials found to be most suitable for ballasting in Canada?

73. The construction of a railway in Western Australia was shown in Fig. 10 which was interesting because the price for excavation in rock in the tenders turned out to be considerably lower than was expected, with the result that the track was realigned in order to have deeper cuttings through the rock and to save the construction of bridges. About seven bridges were saved by having these deeper rock cuttings. The cutting in the figure was over $110 \mathrm{ft}$ deep and the route of the new line was altered, based on the rock cutting prices. Another view of the same cutting was shown in Fig. 11.

74. End-on track laying in East Africa was shown in Fig. 12. The track had been recovered from Tanzania and was brought round by sea in $30 \mathrm{ft}$ lengths, and then a considerable distance over land by rail. In the figure the end-on track laying machine could be seen, working in a somewhat crude but rapid and efficient way. The whole of the new line which was being built had been constructed with that particular machine. A light rail section was used on the new line on the basis that when the traffic increased the rail would be changed to a heavier one. 


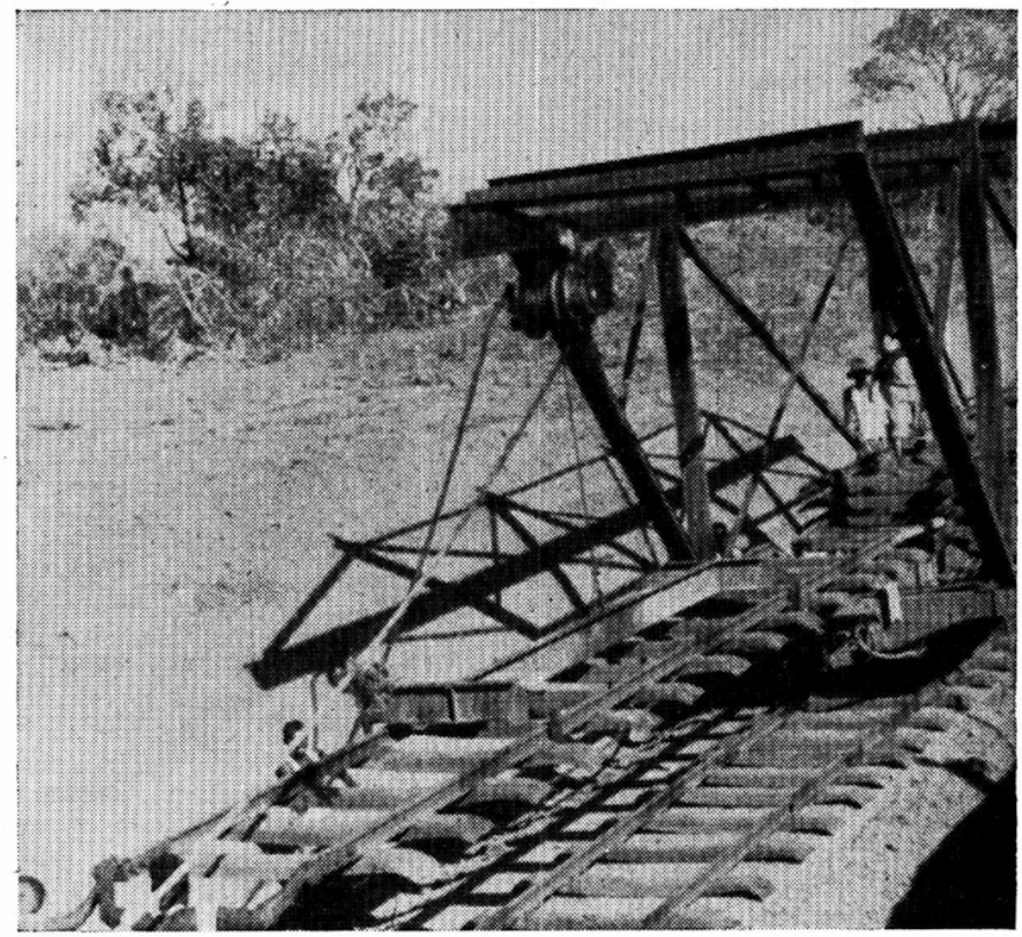

Fig. 12: END-ON TRACK LAYING IN EAST AfRICA

75. Could Mr Johnston state the type of ore wagons being constructed, whether they were side tippers or hopper wagons? He believed swivel couplings were used with side-tippers so that they could be tipped without uncoupling. But this still involved stopping the train for each wagon. What arrangements were there at the ends of the iron ore routes for loading and unloading?

Mr J. E. G. Palmer (Rendel, Palmer \& Tritton) said that his organization had just finished supervision of the construction of a 400-mile length of railway of which they had carried out the complete location and survey, so that they were not entirely ignorant of the subject.

77. Professor Robertson had referred to the question of the aerial survey and mentioned Sir Ralf Emerson's Paper on the Bornu Extension. The whole of this survey was done by aerial photography and photogrammatic methods.

78. It was stated in $\S 15$, 'From these aerial photographs the photogrammetrist will make a detailed photo-analysis, establish vertical and horizontal ground control points .... Mr Palmer stated that his surveyors had found it necessary to send an advance party into the bush to establish vertical and horizontal ground control points before the aerial photography was taken, and it might well be that this was what was done in this case.

79. The points that seemed to him as being of the greatest importance were those that the Author said he should not be questioned upon! In $\$ \S 9$ and 10, under the heading 'Economics', the Author was dealing with a purely hypothetical example of a 
6 million dollar investment by Canadian National Railways, which was presumably a nationalized industry. Mr Palmer understood that the fundamental thesis was that fixed interest charges, amortization and annual maintenance costs, were recovered, and then the haulage cost. A fairly liberal margin for overheads was added and a traffic rate of 10 cents per ton-mile was calculated, which seemed reasonable. It was interesting that the C.N.R. did not insist on recovering their amortization charges, and apparently were prepared to go into this venture with a guarantee of getting approximately $80 \%$ back on their absolutely unavoidable annual charges, but they would take a gamble on the remaining $20 \%$. He felt that this was a most important principle for a nationalized industry to adopt; he did not believe the nationalized industries in Great Britain did that. Was it possible the C.N.R. went in for this semicommercial policy in order to compete with the Canadian Pacific Railway? Was he right in supposing that the Canadian Pacific was still a private venture, and, if so, did the C.N.R. compete with it?

\section{The following contribution was received in writing:}

Mr R. J. E. Brown (Division of Building Research, National Research Council of Canada) wrote that in September 1962 field investigations of permafrost and related terrain conditions were carried out along the Mackenzie Highway in Northern Alberta and the Mackenzie District by the Division of Building Research, National Research Council, Canada. A report of this work was published in June $1964 .^{3}$ Because the route of the Great Slave Lake Railway, extending from Roma, Alberta (near Peace River) to Hay River, N.W.T., closely followed the Mackenzie Highway, site conditions along both routes are very similar. In his Paper, the Author described the use of aerial photographs in route locations (\$\$ 12-15) and referred to permafrost conditions $\S 30$. The main purpose of Mr Brown's contribution was to present additional information on the distribution and occurrence of permafrost along the Mackenzie Highway and to inquire as to the use made by the Canadian National Railways of aerial photographs and other site investigation techniques to assess permafrost conditions.

81. The Author stated on p. 582 that 'It is expected that permafrost will be found only at a few points along the route north of Mileage 250 and mainly in muskeg areas'. Field investigations by $\mathrm{Mr}$ Brown along the Mackenzie Highway revealed that permafrost did occur mainly in muskegs but more widely than the Author suggested. South of Mile 250* permafrost was encountered in muskegs at Miles $245,236,232,227,219,202$, and 142 (the southern extent of the investigations). North of Mile 250, permafrost was more widespread because of the larger and more frequently occurring muskegs and decreasing mean annual air temperatures $\left(30.9^{\circ} \mathrm{F}\right.$ at Keg River, Alberta-Mile $142 ; 24 \cdot 7^{\circ} \mathrm{F}$ at Hay River). Permafrost was encountered north of Mile 250 in more than thirty separate muskeg areas which varied in size from a few hundred feet to several square miles.

82. Investigations of the southern limit of permafrost in Canada and other countries indicated the existence of a broad relation between climate and permafrost distribution. Field observations in western Canada from Hudson Bay to British Columbia indicated that the southern limit of permafrost corresponded roughly with the $30^{\circ} \mathrm{F}$ mean annual air isotherm. South of this isotherm, permafrost occurrences were rare and of small extent. North of the $25^{\circ} \mathrm{F}$ mean annual isotherm, permafrost was widespread and occurred in most types of terrain. The belt situated between these two isotherms had been termed the 'southern fringe of the permafrost region' and it happened to encompass the northern two-thirds of the Great Slave Lake Railway. Within this southern fringe, the distribution of permafrost was patchy and erratic because of local variations in micro-climate and terrain.

* Mileages on the highway and railway are practically identical. In this discussion, mileages refer to the highway. 
83. Permafrost occurred in scattered patches in the drier portions of flat level muskeg areas and in well-drained peat plateaux and ridges which provided 3-4 ft of micro-relief in wet and dry muskegs. The tree growth consisted of stunted, scattered spruce varying in height from 2-20 ft with occasional tamarack, willow, and alder. The ground surface vegetation was a mosaic of sphagnum and other mosses, lichens, Labrador tea, and other plant species. The peat layer varied considerably in thickness, the average being between 2 and $3 \mathrm{ft}$, the minimum encountered being $1 \mathrm{ft}$ and the maximum $9 \mathrm{ft}$. The underlying mineral soil included all types from gravel through sand and silt to clay. The depth to the permafrost table-i.e. the upper surface - in most cases was between 2 and $3 \mathrm{ft}$ below the ground surface, the minimum depth encountered being $1 \mathrm{ft} 8 \mathrm{in}$. and the maximum $5 \mathrm{ft} 6 \mathrm{in}$. The permafrost table occurred usually in the peat rather than in the underlying mineral soil. The areal extent of the patches or islands of permafrost varied from a few feet-around individual trees for example-to several acres. The thickness varied from 1 to $2 \mathrm{ft}$ at the southern limit of the permafrost region to about $40 \mathrm{ft}$ at Hay River (maximum reported depth). The correspondence of permafrost occurrence to the drier portions of muskeg areas appeared to be related to the low thermal conductivity of peat combined with other factors favourable to a negative heat imbalance in the ground.

84. Permafrost occurred also in another type of terrain quite different from the muskegs - the slopes of some river and stream valleys. At the crossing of the Steen River (Mile 267), for example, permafrost was encountered during reconstruction of the highway, $12 \mathrm{ft}$ below the ground surface and extending at least to the bottom of a cut at the 16-ft depth. At Indian Cabins Creek (Mile 287.2), permafrost was encountered $8 \mathrm{ft}$ below the ground surface in a culvert excavation and extended below the bottom of the excavation at the $16-\mathrm{ft}$ depth. The existence of these and other bodies of permafrost at greater depths below the ground surface than those in the muskegs (probably below the depth of seasonal frost penetration) suggested that they were formed during previous climatic periods cooler than the present. The location of a number of these permafrost bodies in the north-facing slopes of east-west river valleys suggested that a slight deficiency in insulation at the surface relative to adjacent flat-lying areas might be a factor contributing to the existence of this permafrost.

85. In view of the patchy distribution and thinness of the individual permafrost islands, it was conceivable that it would cause little concern to railway construction except in the northern portion of the route. Towards the south where permafrost was very patchy, it could be avoided in most cases or removed by stripping and thawing. North of Mile 290, muskeg areas and permafrost were widespread and thus more difficult to avoid. Site investigations in this stretch were particularly vital (as they were throughout the southern fringe of the permafrost region) because of the erratic distribution of the permafrost.

86. Mr Brown and his colleagues wanted to know whether aerial photographic interpretation methods were employed to estimate the location of permafrost islands in relation to terrain features and the railway location. Subsurface soils investigations were described in $\S 27$ without mention of permafrost. Were subsurface investigations carried out in permafrost areas and if so, what techniques were employed and what information was obtained on the areal extent, thickness, ice content, and temperature of the permafrost? Because the temperatures of the permafrost were close to $32^{\circ} \mathrm{F}$ (usually within $1^{\circ} \mathrm{F}$ ), it was difficult to preserve the frozen condition in any construction in the southern areas of the permafrost region. Although initially the frozen condition provided some bearing strength, it was expected that the frozen ground would eventually thaw due to disturbance of the area. In some cases it might be economical to excavate completely small islands of frozen ground underlying a structure, such as railway, and backfill with suitable non-frost-susceptible material, thus eliminating problems due to thawing. It would be interesting to know whether this technique was employed and, if so, what methods were used to 
excavate the frozen ground. It would be useful to learn whether any special precautions were taken with regard to frost heave of small bridge structures, culverts, etc.

87. Finally, the map of Canada (Fig. 2) deserved brief comment because it had a number of serious errors. The shapes of the Labrador-Ungava peninsula, Hudson Bay, and the Quebec-Labrador boundary were badly distorted. The name 'Coast of 'Labrador' had not been used for many years. Labrador was a part of Newfoundland province but this was not obvious on the map. In fact the names of Newfoundland and Nova Scotia were in upper and lower case letters, similar to the cities and towns, whereas the other provincial names were in upper case letters. The Northwest Territories were shown to extend westward to the Alaska boundary, the Yukon Territory being omitted. The positions of Lake Erie and Lake Ontario had been reversed. Finally, in Fig. 3, Fort Smith was shown to be located in Alberta although it was the administrative capital of the Northwest Territories.

The Author, replying to Mr Cantrell, said that the grade of 1 in 166 was chosen because of its adaptability and feasibility in relation to the type of country through which this line would run. This was comparable to the CNR grades on main and secondary lines which generally were reasonable. For instance, the transcontinental route through the mountains to the Pacific Coast has a maximum grade of $0.70 \%$. The other major Canadian railway, the Canadian Pacific, has a grade of about $2.2 \%$ through the mountains and many of the U.S. railways have grades in excess of this. The C.N.R. therefore was in a particularly fortunate position, so far as grades were concerned. Although, in the Province of Newfoundland, where C.N.R. had been operating the railway system, with a $3 \mathrm{ft} 6$ in. gauge, for about 15 years, there were short grades of up to $3.65 \%$ and train lengths had to be established accordingly.

89. The location of the line was dictated to a considerable extent by agriculture and timber conditions. Originally, C.N.R. preferred to construct this line about 200 miles further east, where there was thought to be a greater potential of mineral resources. A Commission of three men was set up by the Federal Government to investigate the entire matter and submit a report with recommendations. After a thorough-going study, a comprehensive report was submitted recommending the construction of the line on the general location it now occupied.

90. The general location of the line was governed by the major topographical features such as river valleys and ranges of hills. The soils investigation had a local and limited effect on the location, by avoiding some particularly troublesome spots. For instance, the original location had one tangent 40 miles in length and subsequently this tangent was broken up into shorter lengths to circumvent questionable soil conditions.

91. A substantial volume of heavy traffic moves down the Mackenzie River to the Arctic Ocean, to support extensive oil and mineral explorations, which are being carried out over a very wide area of the Northern Mainland and Arctic Islands of Canada. There is also a substantial number of permanent and temporary settlements which require supplies.

92. The timber growth on much of this line was very light and aerial photography was carried out when the leaves were off the trees. In this way it was possible to obtain adequate aerial photography to the extent required.

93. Although some permafrost was encountered, this condition was not an important construction consideration. Normal procedure in construction was to leave the existing ground cover of moss undisturbed on the foundation of fills over $4 \mathrm{ft}$ in height. Where permafrost was found in excavation, it was left undisturbed and covered as soon as possible with an insulating layer of granular fill. Actually the material Mr Cantrell referred to in $\$ 47$ would be quite suitable for this purpose. Because of the great distances involved, with no suitable quarry rock available anywhere within the entire area, there was no alternative but to use run of pit ballast 
wherever it could be found. Subsequently the entire line was to be given a final lift of washed and crushed ballast, but this also had to be produced from native pits of gravel.

94. Mr Cantrell's impression that the track was laid on one side of the $20 \mathrm{ft}$ wide grade was mistaken. The track structure was designed and intended to be laid along the centre line of the grade and as it turned out the design width of $20 \mathrm{ft}$ on top of grade was none too adequate. Subsequently, it became necessary to go back and widen the top of grade to $24 \mathrm{ft}$ over the first 170 miles of the line in order to provide a subgrade wide enough to support the ballast section, with lifts up to three and four feet in places, and to provide for future erosion of the shoulders of the embankment. The high ballast lifts were necessary in order to blanket and suppress the swelling clays in the grade and prevent them coming right up through the ballast. The Author had seen many points on this line where large lumps of plastic clay came up through as much as 18 in. of ballast and out through the spaces between the sleepers in the track structure.

95. Professor Robertson had underestimated the tonnage which could be handled in a single train in Canada. For instance it was originally planned to handle 8000 revenue tons per train consisting of 80 cars, each capable of transporting 100 net tons. A train of this size could be handled by four diesel locomotives and if necessary trains up to 10000 revenue net tons could be handled over this line with the addition of one extra locomotive unit. On this basis the original estimated annual production of the mine concentrator could be handled by one round trip per week. However, there was every indication that the annual production would be substantially increased and it was expected that two round trips per week would be operated which would produce a much improved car cycle offsetting the additional cost for train operation.

96. Professor Robertson also made reference to the apparent high transportation costs. These transportation costs did not apply to the new line only; they also covered the transportation involved over existing lines and this might be 500, 1000 or 2000 miles more than the length of the new line which had been built. However, the economics outlined in $\$ \$ 9$ and 10 were prepared for an imaginary but typical branch line, and all the figures covered a combination of costs for the proposed new branch line and transportation over long distances of existing lines.

97. The figure of $\$ 2000$ per mile covered the fixed maintenance cost of the branch line which was the minimum maintenance cost when the traffic guarantee would become applicable.

98. Referring to Professor Robertson's query in § 51, the Author said that $\$ 14$ attempted to outline the mechanics or specification details of aerial photography as used by C.N.R. in Canada. On the other hand $\S 15$ was intended to explain the alternative methods of calculating quantities of materials in open country as compared to heavily forested areas.

99. Quantities of materials were calculated only once either from the original photography in open country, or after clearing had been completed and the line rephotographed in heavily-forested country.

100. It was intended in $\S 33$ to deal only with construction sizes and quantities of drainage structures. The details of drainage and run-off investigation mentioned by Professor Robertson were routine and standard engineering procedures in new railway line construction in Canada, and elsewhere, which did not warrant specific mention, in the opinion of the Author.

101. In Canada, tractive effort was not related directly to the weight of rail. Total tractive effort may be increased by adding more diesel locomotive units, while the individual axle loading remained unchanged. Weight of rail was linked more directly to the spacing and loading of axles. On the Great Slave Lake Railway the 100-ton capacity ore cars would have an axle loading of $66000 \mathrm{lb}$. 
102. Maximum grades of $0.60 \%$ were established in each direction for the reasons mentioned by Professor Robertson.

103. Replying to Mr Butland, the Author said that the C.N.R. made use of the analytical method known as discounted cash flow, which was also known in Canada as the investor methods'.

104. Although the critical path method was widely used on C.N.R., it was not used, in the network form, on the G.S.L.R. Project.

105. Train speeds were still under consideration, but it was expected that maximum permissible speed would be $40 \mathrm{miles} / \mathrm{h}$. As mentioned previously the axle weights on rail would be about $66000 \mathrm{lb}$ for the ore cars. The $85 \mathrm{lb}$ rail referred to was the nominal weight of new rail, as rolled. It would have an actual weight of something less than $85 \mathrm{lb} / \mathrm{yd}$ because of previous wear in other locations. In Canada part worn rail was always identified and referred to by the branded weight stamped on the webb.

106. The standard system of soil tests used were standard proctor tests carried out in the laboratory with subsequent field tests to confirm that the soil was compacted to the specified density. The field tests were mostly done using the oil immersion method on clay soils and the balloon method on other soils.

107. Although some preliminary air and ground reconnaissance had been made previously, the first actual survey was started in January 1961, and completed in November 1961. Tenders for clearing and grading were invited separately. Clearing was started in January 1962, and grading in late spring 1962. Tracklaying was started in August 1962 and was completed in November 1964. Final ballasting would be continued during the working season of 1965 .

108. Most of the country through which this railway was built was virgin land-owned by the Provincial Government in Alberta, and by the Federal Government in the North West Territories. The southerly portion of the line ran through a few settled areas and grain farms. The first approach in these areas was to obtain the land for right-of-way purposes by negotiation. When this method failed, as it did in several cases, the railway had the necessary parliamentary authority to take possession, which was known in Canada as the right of expropriation. Compensation was established subsequently by further negotiation, or eventually by an exchequer court.

109. Replying to Mr Smith, the Author said that in Northern Canada road surfaces were severely damaged by winter weather conditions, particularly when thawing occurred in the spring. This condition was aggravated by the traffic, and load restrictions were imposed on all heavy vehicles during the period of spring break-up. Main highways and all-weather roads were constructed principally by the province concerned while the Federal Government had jurisdiction over the major railways. In addition, the demands of owners of private passenger automobiles had an important influence on highway construction. Railways were usually constructed or maintained to handle the heavy bulk traffic.

110. The normal method of keeping switches clear at outlying points and on less important lines was by manual labour. On a line such as the G.S.L.R., gangers were stationed at specified intervals for general maintenance, and part of their job was to keep switches clear of snow. On main line tracks, where there was centralized traffic control, switch heaters had been installed - of various types-operated by fuel oil, natural gas, electricity or propane gas.

111. There was a problem of frost heaving on most railway lines in Canada which did not have an adequate ballast section or drainage, and with a subgrade built of mixed materials. The severity of frostheaving was more directly related to the type of subgrade material than the presence of permafrost, either solid or intermittent.

112. In those areas where heaving occurred, track shims were used between the plate and sleeper to maintain a reasonably even surface and avoid as much as possible the need for speed restrictions.

113. All track construction had been done by railway employees' direct labour, 
or by special contractors on a cost plus small fee basis, and no comparative costs were available.

114. Standard track construction in Canada was of the type described and no other types of fastenings had been tried on new branch line construction.

115. No consideration was given to continuous welded rail on new branch lines, as initial subgrade and ballast conditions would be inadequate to restrain it, with a temperature range which could reach a maximum of $150^{\circ} \mathrm{F}$.

116. Because of the consolidation of the grade which was inevitable for several years after construction, in the severe climatic conditions of Northern Canada, a good granular gravel ballast was the most practicable, and economical. Crushed quarry rock was preferable on higher density traffic lines which were well consolidated. However, on the G.S.L.R. there was no suitable quarry rock, which could be reached, within hundreds of miles.

117. The ore wagons finally chosen, and now being constructed, were of the bottom discharge hopper type, with standard automatic couplers and two-axle bogies. The gross weight of each wagon was $263000 \mathrm{lb}$, with a tare weight of $63000 \mathrm{lb}$ and a load capacity of $200000 \mathrm{lb}$. The ore being carried was a lead-zinc concentrate, with some other trace metals. The loading arrangement at the concentrating plant was from overhead bins and chutes. At the unloading point the concentrate was dumped through the bottom hoppers of the wagon into undertrack storage bins from which it was taken by conveyor to the smelter. This unloading arrangement had been in existence for a long time, serving the smelter, and governed the choice and details of wagons being constructed for the Pine Point Mines traffic.

118. Replying to Mr Palmer, the Author said that $\S 15$ was intended to outline alternative methods of aerial photography depending upon the nature of the country. Generally it was the practice to establish vertical and horizontal control points, by ground parties, before final aerial photography was carried out. In retrospect this paragraph would have been clearer in meaning had it been worded-'identify previously established vertical and horizontal ground control points'.

119. Although Canadian National Railways was publicly owned, it was not a nationalized industry in the popular sense of the term. It was organized as much as possible on the lines of a private company with a president, a board of directors, and authority to borrow funds directly in the open market for capital expenditures. It had the responsibility and was required to pay the interest and carrying charges on its outstanding indebtedness. It was competitive, in every respect, with the Canadian Pacific which was privately owned by individual stockholders.

120. Replying to Mr R. J. E. Brown, the Author said that although the Great Slave Lake Railway could not have been built without encountering some permafrost, this condition was not an important construction consideration. Permafrost was confined mainly to muskegs which were avoided as much as possible and to northfacing river banks on which substantial fills were usually placed. Normal procedure in construction was to leave the existing ground cover of moss undisturbed on the foundation of fills over $4 \mathrm{ft}$ in height. Where permafrost was found in excavation, it was left undisturbed and covered as soon as possible with an insulating layer of granular fill. This procedure was followed at about a dozen culvert sites, using granular pads $3 \mathrm{ft}$ thick.

121. The marginal economics of branch railway construction forbad any thought of excavating small islands of permafrost and backfilling with granular material, as Mr Brown suggested. Unless the ice content of the frozen ground was considerable it was cheaper to make up any small settlements which occurred by surfacing track during operations. In fact, no subsidence of grades or heaving of bridges or culverts had so far been attributed to melting of permafrost. In the Author's experience on other northern lines, the heaving of bridge bents did not become a significant problem where the mean annual air temperature was above $23^{\circ} \mathrm{F}$.

122. No special techniques were developed to detect permafrost in test borings. 
This was because it was difficult to differentiate from annual frost except in those borings made in autumn or early winter and, as $\mathrm{Mr}$ Brown indicated, the permafrost was of limited thickness except at the northern part of the line.

123. Air photos were not used to locate permafrost islands. As mentioned, these are found mainly in muskegs which were by-passed. At one time, arrangements were discussed to take air photos of the route with sensitive infra red film to see if differences in heat between permafrost and non-permafrost areas would be apparent. This experiment was part of a larger investigation which, unfortunately, was not completed.

124. Figs 2 and 3 were included to show the location of the G.S.L.R. relative to the balance of the Canadian National Railway System. It was regretted that some errors occurred in other incidental details.

\section{REFERENCES}

1. Emerson Sir Ralf. A project for extending the Nigerian railway into Bornu province. Proc. Instn civ. Engrs, 12, (March) 1959, 353-66.

2. Wellington A. M. The economic theory of the location of railways. Wiley, New York, 1903.

3. R. J. E. Brown. Permafrost investigations on the Mackenzie Highway in Alberta and Mackenzie District. Technical Paper No. 175, National Research Council Canada, Division of Building Research, June 1964, pp. 27 (NRC 7885). 